\title{
Reconnoitring the nexus between Development and Sustainable Development
}

Oludele Mayowa SOLAJA and Obatunde Bright ADETOLA

Department of Sociology

Olabisi Onabanjo University

Corresponding email address: solaja.oludele@,oouagoiwoye.edu.ng

\begin{abstract}
Development and sustainable development are two concepts gaining the attention of scholars, historians and policy makers in recent times. This is because they represent what people and societies across the world today sincerely desired. Every human being or human society deserve improvement in quality of livelihood, health care system, access to food, housing, security, clothing and many other indices of development in a sustainable manner. Based on this momentum, this paper examines the nexus between development and sustainable development. The paper is divided into four sections. The first section spots the conceptual issue woven around the term development as well as sustainable development in literature. The second section clarifies the two concepts (development and sustainable development) and the main perspectives on development were discussed. It also identifies the common and distinctive features between the concept of development and sustainable development. The third section then presents a conceptual framework of analysis on the nexus of between development and sustainable development. Finally, the paper concludes that the duos (development and sustainable development) are two-side of a coin and they complement each other. This is due to the fact that development is people oriented hence it must be sustainable so as to ensure that the advancement of current generation does not deny future generation the opportunity to develop.
\end{abstract}

Keyword: improvement; opportunity; people; perspectives; society; sustainability

\section{Introduction}

The terms development and sustainable development continue to be a central focus of modern sociological discourse, but they are subjects of conceptual and theoretical debates. The terms are sometimes used by scholars in contradictory ways. As two debatable concepts, development and sustainable development have been offered several definitions in which an attempt to arrive at a concise and a generally acceptable definitions seems to be problematic due to scholars' bias and ideological proclivities (Okolie, 2003). As such, evidences abound that there is current misconception of the term 'development' to mean 'sustainable development' and 
vice-versa mostly among policy makers. This fallacy of knowledge has become the fundamental impediment to the conceptual definition, explanation and understanding of both concepts. Thus, it is now time to clarify and brush aside the web of conceptual issue woven around the term development as well as sustainable development in order to enable us to know more precisely what both concepts mean.

Understanding the meaning of the term development and sustainable development would enable us to envisage what post 2015-sustainable development goals (SGDs) should look like and how to pursue them; to devise meaningful measures of progress and thus to assist in scheming policy document both at national and international levels. The two concepts (development and sustainable development) have many features in common as well as some distinctive characteristics. Both the common and distinctive features would be highlighted and discussed with the view to present conditions through which the two concepts can be used interchangeably.

\section{Concept of Development: An overview of major perspectives}

Development is imbued with people's imageries and visions of a better life - a life which is materially enriched, ecologically improved, institutionally well-organized and technologically more advanced. Another salient feature of development is that it is a word concerned with value placement and it connotes improvement arising from unintentional and intentional activity carried out by people (individually or collectively) residing in a particular geographical entity (Cowen and Shenton, 1998). Development is a gradual but constant improvement in social institutions that made up the social system. Development is neither an automatic improvement in social institutions nor a process that can be fast forwarded by any agents/factors of development that are under-utilized or poorly implemented. Thus, development is a long-term process of 
structural societal transformation (Thomas 2004). According to Gore (2000), the word development in the 50s and 60 s mean a vision of the liberation of people and peoples' dominated based on structural transformation. However, this interpretation of development has slip away for many authors in development literature.

Still in the sixties, the term development used to be referred to as "modernization" brought about by westernization (Eugene and Eme, 2014). Westernization can be defined as the changes in social institutions as a result of foreign domination or external control of local economies (Rostow, 1960; Coleman, 1968; Pye 1973). Foreign control of local economies may arise from coercive exploitation of resources by external forces or domination of imported goods and services in local markets (Omobowale, 2013). Another instance stemming from modernization theorists is the optimism that development is tantamount to economic growth that is technically driven by industrialization. Industrialization is an act of production and distribution of goods and services in large quantity which started in Europe around late 18th century (Godson and Mynepalli, 2007; Brandon, 2004).

Some modernization scholars such as Moore (1963), Rostow (1960), Coleman (1968) and Pye (1973) also view development as tantamount to industrialization by positing that development connotes transformation of a traditional or pre-modern society to categories of technology and associated social organisation that describe the 'advanced' economically rich and politically stable nations of the western world. To buttress their claims, Rostowian (1960) presents five stages of development which are;

1. Primitive society: the stage is characterized by subsistence farming and barter trade` 
2. Preparation for take-off: the characteristics of the stage are specialization, production of surplus goods and trade. Transport infrastructure is developed to support trade and above all the stage encourages savings and investment.

3. Take-off: at this stage industrialization increases and the economy switches from agriculture to manufacturing

4. Drive to maturity; at this stage the economy diversifies into new areas and there is less reliance on imports.

5. Period of mass consumption; at this stage the economy gears on mass production and service sector becomes increasing dominating.

Based on the Rostow's analysis, development can simply be conceived as a dominant discourse of western modernity (Foucault, 1969). That is, it portraits the progress accomplished in the post-Renaissance period of European history (Passmore, 1970). To substantiates this position, the works of Hickey and Mohan (2003) and study conducted by the Institute of Development Studies (2007) revealed that among the post-modernists; development is seen as a discourse (a set of ideas) that appreciates or values certain things (which could be economic, spiritual or cultural assets) over other in a bid to shape and reframe reality and power relations.

In contrast to the above perspective, other scholars like Seers (1972), Mabogunje (1981), Rodney (1982), Okolie (2003) and many others from the dependency school of thought disassociated and disagreed with the modernist explanations. For them, the modernist explanations on the stages of development glassed over the role of colonization and the repatriation of resources from South to North (which lasted for about 500 years) in the development' of the West. The dependentists also maintain the view that modernization theorists underestimate the role of human resource (people) in development (as both the object and subject 
of development). This is because; development is about people and is the people that will bring about the kind of development they desired. In this regard, Okolie (2003) apprehends development as man focused and driven by socio-economic and political alteration of self and entire structure of a given political system from a comparatively low level to a more qualitatively and remarkably improved level. According to Eugene \& Eme (2014), the main goal of development is to improve the living conditions and material standing of the populace. Corroboratively, UNDP (2004) report designate that people are the real wealth of nations hence the basic purpose of development is to enlarge human freedoms. Freedom from any form of servitude or threat both internally and externally. This substantiates the fact that process of development supposed to expand human capabilities by expanding the choices that people have to live full and creative lives which imply that people are both the beneficiaries of such development and the agents of the progress and change that bring about it (UNDP Human Development Report, 2004). Thus, development as a concept goes beyond the lines of what poor nations should do to become richer, or simply asking for assistance (financial or nonfinancial) from developed countries, to a well-encompassed direction towards ensuring simultaneous growth in social, economic and environmental conditions that aid the ability of the people to meet their imageries and visions of a better life (Solaja, Omobowale \& Alliyu, 2015). A better life is the ability to lead a healthy life and to contribute meaningfully towards attaining improvement in the social institutions when the socio-economic, health, political and religious barriers constraining their (people) capabilities and potentials to develop has been removed.

Furthermore, it is also observed in literature that development has been taken to represent any activity that aim to compare the socio-economic accomplishments of two or more societies in a bid to determine which one is experiencing desirable improvement- good change 
(Chambers, 2004). The question that comes to mind at this juncture is; what is good and what sort of change matters. The closest answer that can be offered here is that whatever is inspiring, attractive, enhancing and worth striving for is a good thing. In terms of good change, one can assume that any change or alteration in the social system that tends to enhance the quality of life, standard of living and environmental worth is a good change. This view of good change, as Kanbur noted, is one that best describes what development means (Kanbur, 2006). Thomas (2004) also observed that good change entails the need for poverty reduction and attainment of the Millennium Development Goals (MDGs) as demonstrated by international development donor agencies. Therefore, development can be construe to mean short-to-medium term outcome of desirable targets.

\section{Meaning of Development}

Based on the discussion above, attempt is made in this section to define development. A critical review of literature showed that the first usage of the term development was to describe the progressive movement of the United State of America from the position of developing to a developed state in 1949 in a statement made by former US president, Harry Truman:

We must embark on a bold new programme for making the benefits of our scientific advances and industrial progress available for the improvement and growth of underdeveloped area... the old imperialism-exploitation for foreign profit-has no place in our plans. What we envisage is a program of development based on the concepts of democratic fair dealing (Allen and Thomas, 1992:06).

Meanwhile, the United Nations Development Programme (1990) defined development as to lead long and healthy lives, to be knowledgeable, to have access to the resources needed for a decent standard of living and to be able to participate in the life of the community. From an expansive view, Alliyu (2010) regard development as a state of being and a process'. He stated 
that it is a state of being whereby society has transcended above certain barriers or obstacles to human comfort and existence through the conscious management of the internal resources of the society at a point in time couple with ability to cope with external influence. On the other, as a process, development mean the various mechanisms consciously put together or harnessed by the people over a period such that it causes transformation of the society from a state to another which can be definable as 'developed' at a state. More so, Obono (2012) conceived development as the improvement and attainment of core value of sustenance (that is the perpetual ability to meet basic needs), self-esteem (what it means to be, and to have respect to the fact of one's being, a person), and freedom from servitude (or the ability to choose and change a particular lawful existential aspirations). Odufuwa and Wahab (2015) opined that development encapsulates capacity of government or system to manage resources efficiently, to enhance the well-being of the populace. Hence, government can support or obstruct process of development. Development is therefore conceptualized at the levels of the individual, social group and government (Iornumbe, 2005).

Similarly, a number of scholars have argued that development must take into account the qualitative improvement in employment, social justice and equality. Implicit in every use of the term 'development' however, is the notion that some countries and regions of the world are extremely poor whereas others are very prosperous. For instance, one would agree that citizens of developed countries of the West enjoys more desirable life while the citizens of the Third world countries and Nigeria in particular languished in poverty evidenced by high prevalence of famine, disease, war and ignorance in spite the plentiful economic resources (Matunhu, 2011; Olutayo and Bankole 2002). This observation rings a bell of the inimical assumption of Webster (1984) who submitted that countries with high poverty rate are geographically located at the 
bottom of the earth's surface while those on upper earth's surface have very low level of poverty. However, Olutayo and Bankole (2002) revealed the key rationale for variation in poverty rate between North and South is the fact that countries at bottom part of the earth's surface experienced serious colonial turmoil in the past and they also have low Gross National Product (GNP) because they depend mostly on limited primary products for export when compare with those on the upper surface of the earth. Thus, they are referred to as Third World nations. Correspondingly, Ricupero (1997) and Tomlinson (2001) revealed that cultural interactions in modern history of imperialism and post-colonialism, world-systems, underdevelopment or socioeconomic change over the last five hundred years were also reasons for high rate of poverty in Third World countries including Nigeria. Although, this paper conceived that it is embarrassing to continue to attribute high poverty rate and underdevelopment status of Nigeria to her colonial experience after fifty-six years of independence. Rather it should be seen from the angle of inability of the government to manage and channel her stupendous natural and human wealth towards reasonable development. Achimugu, Abubakar, Agboni, and Orokpo,(2012) emphasized that given Nigeria's huge natural resource base for which it earned over US \$ 300 billion (from crude oil alone) in the last three decades, as well as the promising options available in agriculture, tourism and solid minerals, Nigeria indeed should have no business with being poor. Thus, we can succumb to assertion made by Akanle and Abayomi (2013) that 'even when development is desirable, not all development and associated efforts are sustainable'. This view drives us to the concept of sustainable development.

\section{Sustainable Development}

The term "sustainable development" has been explained from diverse viewpoints. Historically, the concept materialized from the theoretical postulations of modern economists 
like Malthus and Ricardo who had predicted resource limitation as the major impediment to future economic growth. This informed the report given by the World Conference on Environment and Development (WCED) known as Bruntland Commission, on the concept "Sustainable Development" which has gained international recognition (Alao, 1995). Sustainable development is a concept, goal and movement towards building the capacity of current generation to meet its needs and develop without jeopardizing the opportunity of the future generations to meet theirs and develop (Brundtland 1987, Stoddart, 2011; Akanle, 2014). It is a process of change in which the social and ecological resources consumed are not exhausted to the extent that they cannot be renewed and with the view that the creation of wealth within the community must considered the wellbeing of both the human and natural environments presence in the community (Prucnal-Ogunsote, Okwoli \& Ude, 2010). In other words, sustainable development is a kind of developmental approach that promotes intergenerational equity, accessibility, compatibility and quality control of the environment. It also includes concerted efforts to achieve improved quality of life for all, and to enable multi-stakeholder groups to define their vision of sustainability and work towards it. This, according to Hill, McMillan, Farina (2003) has the following features:

- An ethical, empowered and personally fulfilled individuals

- A well-defined community built on collaborative engagement, tolerance and equity

- A sound social system and institutions that is participatory, transparent and just

- Perception of environment practices that value and sustains biodiversity and life-supporting ecological processes

Corroborating the view above, Botanic Garden Conservation International (1999) affirmed that achieving sustainable development means adopting and implementing policies concerning issues 
such as recycling, energy efficiency, conservation and rehabilitation of damaged landscapes for the wealthy nations. While it means developing policies for equity, respect of the law, redistribution of wealth and wealth creation for the developing nations. More so, the essence of environment in the process of achieving sustainable development cannot be underrated. Proponents of sustainable development also affirmed that without productive environment to provide a resource foundation, it would be difficult or impossible to envision attaining sustainable society (Kate, Parris and Leiserowitz 2005; Morelli, 2011).

\section{Development and Sustainable Development: A conceptual analysis}

The goal of this section is to engage in conceptual analysis of the connection between development and sustainable development within the context of literature. Before embarking on these voyages of enquiry, it must be borne in mind that development does not simply mean increased economic growth (which has often been erroneously equated with progress), measured in terms of Gross Domestic Product (Dowarkasing, 2013). It goes beyond the lines of economic indices or what poor nations should do to become richer, or simply asking for assistance from developed countries, to a well encompassed focus on the improvement in the environment, social and economic conditions to meet people's imageries and vision of a better life (Solaja, Omobowale and Alliyu, 2015). The process of achieving a better life for the populace must be reserved in a sustainable manner without resulting to resource impartiality or inequality between the present and future generations. However, in order to fully capture the essence of the section, an illustration is presented below. 
Fig.1: Nexus between Development and Sustainable Development

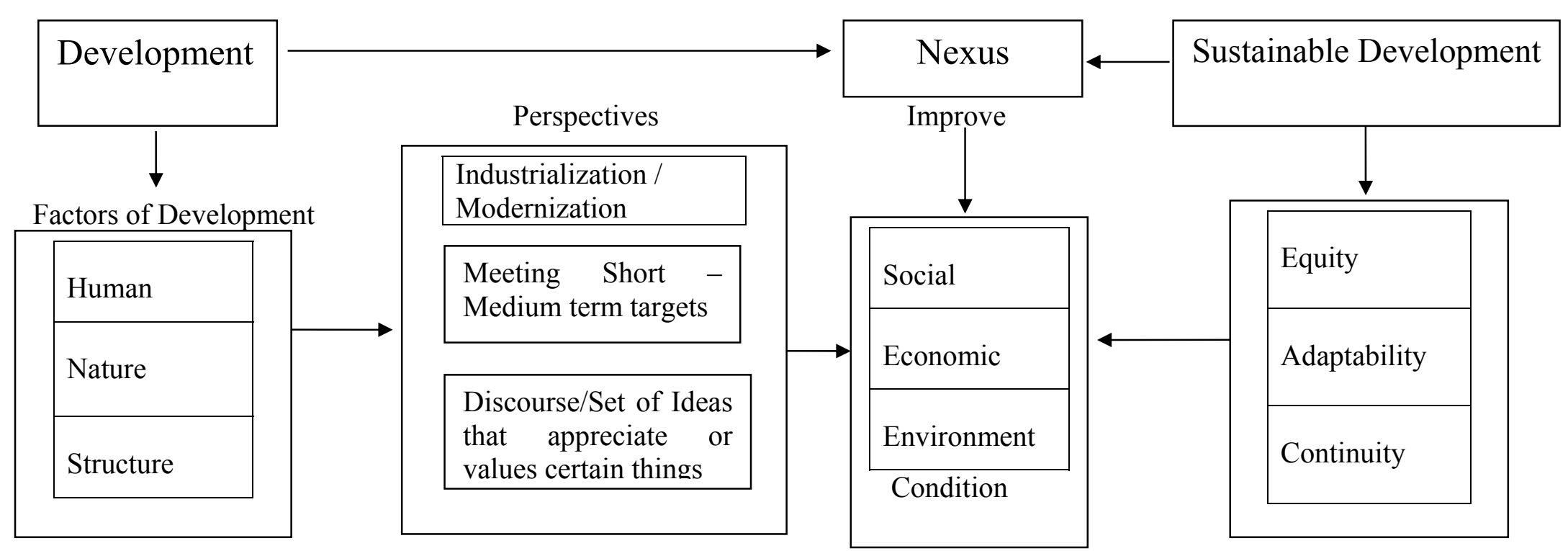

Source: Conceptual framework on the nexus between Development and Sustainable Development 
The diagram above illustrates the conceptual link of the term development and sustainable development in contemporary literature. Contemporary studies on development, which form the basis of the conceptual approach, identify three key factors of development which include human, nature and structure (Booth, 2004; Corbridge, 1995). These factors are very crucial to achieving development in any given society. For example, human resource is the people (skilled and unskilled) who are the subject and object of development. They are the subject of development because development depends on peoples' definition or insight.

It is what the people conceive to be development that determines the form of development that will be pursued or achieved by them. That is to say, the people have an internal sense of what is good change or desirable targets which they work toward achieving. Also, they are the object of development because their perception and evaluation of human society determines the understanding or knowledge they have about development. Interestingly to note here is the fact that people also possess subjective and objective indicators of developmental progress (Conceição and Bandura, 2008). Both subjective and objective indicators must be incorporated in order to have a clear picture of what development should be. More so, nature (comprising of mineral and natural resources) predicts the level or dimension of development that can be attained in every society. Nature serves as the resource foundation upon which the edifice of development is built. The quality and quantity of resources available to drive development determine the extent to which improvement in social, economic and environmental conditions can be realized. However, evidences have shown that most societies with huge resources experience a situation called- resource cause- which undermined their development process (Nigeria is a case on point). The structure put in place by the people also play vital role in development process. Structure includes the processes, practices and mechanisms adopted by the 
people in transforming or utilizing the resources available to achieve development. The structure of development could be based on traditional subsistence agriculture or a more advance, urbanized or industrially diverse manufacturing and service economy (Seers, 1983).

Furthermore, development is based on perspective which the people embraced in the course of attaining good change in social, economic and environmental conditions. There are three main perspectives on development. These perspectives include;

i. Industrial-based/modernization perspective with more emphasis on production and exportation of goods and services

ii. Setting and meeting short-medium term targets through international and national collaboration

iii. Set of ideas that appreciates or values certain things over another

All these perspectives, however, aimed at achieving positive improvement in social, economic and environmental conditions. It is at this point that the idea of development intersects with the concept of sustainable development. To buttress this assertion, Bruntland commission defined sustainable development as a process of change in which the exploitation of resources, the direction of investments, the orientation of technological development and institutional change are all in having and enhance both current and future potential to meet human needs and aspirations (World Conference on Environment and Development, 1987). Moreover, the idea that development effort must be socially, culturally, physically, environmentally and structurally compatible, adaptable and sustainable show the connection between development and sustainable development (Akanle and Abayomi, 2013). The connection between the two concepts (development and sustainable development) rests on the fundamental principle that people or government must promote developmental actions that are inclusive and can bring 
about sustainable improvement in social, economic and environmental conditions. Thus, the two terms can be used interchangeable when the idea or purpose of discussion focuses on inclusive or sustainable growth. Sustainable development in general term has three basic components which are; equity, adaptability and continuity. Equity depicts ability to minimize the consumption of natural resources for provision of adequate and affordable basic needs of life for the present generation in order not to jeopardize the prospects of subsequent generations to develop. Adaptability represents the notion for inclusiveness in the process of distributing basic needs of life so as to address the issue of poverty, deprivation, and inequality between and within people, communities and nations. In addition, continuity illustrates the need for constant resource supply for the purpose of sustaining the pace of development from one generation to another.

\section{Summary and Conclusion}

Arising from the discussion above, development can be seen as deliberate efforts to eliminate limitations affecting human beings in a bid to promote an inclusive and participatory society. An inclusive and participatory society implies increase freedom, creativity, self-discipline, responsibility and material well-being. It also connotes reduction of socio-economic hardship, barriers to lead a healthy life, ignorance, and physical incapacitation to meet basic needs of life. It is therefore disclosed that development means that improvement in peoples' lives and capacity to impact their social environment positively without any form of limitations. In the same vein, sustainable development is presented as a kind of notion which advocate for equity, accessibility, compatibility and quality control of resources between present generation and future generation. It emphasized that the development of present generation should not defer the opportunity of future generation to develop socially, economically and environmentally. Thus, the duos (development and sustainable development) are two-side of a coin and they complement each 
other. They both epitomize the idea of improvement in social, economic and environmental conditions of a particular society, through which the people living in that society can enjoy quality standard of living and freedom from any form of servitude or threat. People's freedom from servitude or threat can only be achieved when there is a good change across factors or institutions responsible for a better life- a life which is materially enriched, ecologically improved, institutionally well-organized and technologically more advanced. This was also be reiterated by Todaro (1985) who noted that development must represent the entire gamut of changes by which an entire social system, tuned to the diverse basic needs and desires of individuals and social groups within that system, moves away from a condition of life widely perceived as unsatisfactory, and moves towards a situation or condition of life regarded as materially and spiritually 'better'. However, sustainable development laid more emphasis on the need to make development sustainable for both present generation and future generation through resource conservation and eco-friendly approach to development.

\section{References}

Achimugu, H., Abubakar,Y.I, Agboni, J.U and Orokpo, J.O (2012) Rethinking Poverty Reduction and Sustainable Development in Nigeria: An Advocacy for the Buttom-Top Paradigm. Canadian Social Science Journal.Vol. 8, No. 6, 2012, pp. 78-90

Akanle, O. and Abayomi, A.A (2013) Sociology of Development, in R. Aborisade, Omobowale, A.O and O. Akanle (ed) Essentials of Sociology, Ibadan University Press, Ibadan, pp. 395- 411

Alliyu, N. (2010) ‘Daniel’s Development Profile In Ogun State, Nigeria, pp. 30-31

Booth, D. (2004) Fighting Poverty in Africa: Are PRSPs Making a Difference? London: ODI

Botanic Gardens Conservation International (1999). Registered Charity no. 1098834 at the Charity Commission

Brundtland (1987). Our Common Future. Report of the World Commission on Environment and Development: United Nations Document

Chambers, R. (2004) Ideas for Development. IDS Working paper 238. Sussex: IDS 
Coleman, J. S. 1968. Modernization: Political Aspects, in Sills, David L. (ed), International Encyclopedia of the Social Sciences, New York, Macmillan, 10: 10-70.

Conceição, P. and Bandura, R. (2008) Measuring Subjective Wellbeing: A Summary Review of the Literature.' Working Papers, edited by UNDP New York: United Nations Development Program

Cowen, M., and Shenton, R. (1988) Doctrines of Development. London: Routledge.

Eugene, O and Eme, O. I. (2014). Role of the Youths in National Development. Singaporean Journal of Business Economics, And Management Studies Vol.3, No.2 pp. 164-181

Gore, C. (2000) The rise and fall of the Washington consensus as a paradigm for developing countries, World Development, 28 (5):789-804

Hackey, S., and Mohan, G (2009) "Participatory Development from Epistemological Reversals to Active Citizenship". Geography Compass Vol. 1 (4) pp779-780

Hickey, S. and Mohan, G. (2003) Relocating Participation within a Radical Politics of Development: Citizenship and Critical Modernism. Draft working paper prepared for conference on Participation: from Tyranny to Transfromation? Exploring new approaches to participation in development, 27-28 February 2003, University of Manchester, Machester.

Hill, K., McMillan, G., Farina, R. 2003. Hunting-related changes in game encounter rates from 1994 to 2001 in the baracayu Reserve, Paraguay. Conserv Biol. Vol.17:1312-1323.

Iornumbe, G. (2005). Political Instability and National Development in Nigeria. NAPSS Journal of Politics and International Relations, 4(1), 27-37.

Kanbur, R. (2006) What's Social Policy got to do with Economic Growth? Available at http://www.arts.cornell.edu/poverty/kanbur/ (accessed 1 August 2005).

Kates, W.R., Parris, M.T and Leiserowitz, A.A (2005). What is Sustainable Development?

Goals, Indicators, Values, and Practice. Environment:Science and Policy for Sustainable

Development, Vol.47(3) pp:8-21

Mabogunje, A.L. (1981). The Development Process; A Spatial Perspective, London, Hutchinson Publishers.

Matunhu, J. (2011) "A critique of Modernization and Dependency Theories in Africa: Critical Assessment”. African Journal of History and Culture Vol. 3 (5), pp. 65-72

Moore, W.(1963). Social Change. Englewood Cliffs, N.J.: Prentice-Hall

Morelli, J. (2011). Environmental Sustainability: A Definition for Environmental Professionals. Journal of Environmental Sustainability: Vol. 1(1) pp:1-9 
Obono, O. (2010). "The Role of Civil Society in Nigerian National Development." The Role of Civil Society in National Development. Accra: West African Civil Society Institute.

Okolie, A. (2003). Producing knowledge for sustainable development in Africa: Implications for higher education. Higher Education, 46(2), 235-260.

Olutayo and Bankole (2002) "Concept of Development in Historical Perspective" In Uche C. Isiugbo-Abanihe, Austin N. Isamah and Jimi O. Adesina (Eds), Currents and Perspectives in Sociology. Malthouse Press Limited, Ibadan.

Omobowale, A.O. (2013). The Tokunbo Phenomenon and the Second-hand Economy in Nigeria. Peter Lang, Oxford.

Passmore, J. (1970). The Perfectibility of Man. London, Duckworth.

Prucnal-Ogunsote, B., Okwoli, F. J. P. \& Ude, O. A. (2010). Progress and Prospects of Promoting Sustainable Architecture through Education in Nigeria. Proceedings of the Architects Registration Council of Nigeria (ARCON) 3rd Architects Colloquium. Theme: Architecture and the National Development Agenda III. 19 - 21 April 2010, Abuja.

Pye, L. W. (1973). The Concept of Political Development, In Kebshull, H. G. Ced, Politics in Transional Societies, New York, Appleton.

Ricupero, R. (1997) Reconciling the Creative Forces of the Market with the Needs of the Disadvantaged, South Letter, Vol. 1 and 2 no. 28

Rodney W (1972). "How Europe Underdeveloped Africa”. Dar es Salaam: Tanzanian Publishing House.

Rostow, W.W (1960) "The Stages of Economic Growth": a Non-Communist Manifesto. Cambridge: Cambridge University Press.

Seers, D. (1972) What are we trying to measure? Journal of Development Studies, 8 (3):21-36

Stoddart, H. (2011). A Pocket guide to sustainable development governance. Stakeholder Forum.

Solaja, O.M, Omobowale, A.O and Alliyu, N (2015). The Dimensions of Environmental Pollution in Lagos Metropolis, Nigeria. Journal of Sustainable Development in Africa. Vol. 17 (3A) pp: 96-115

Thomas, A. (2004) The Study of Development. Paper prepared for DSA Annual Conference, 6 November, Church House, London.

Todaro, M. p., (1985) "Economic Development in the Third World" New York and London

Tomlinson, B. (2001) Materials development. In R. Carter and D. Nunan (eds.) The Cambridge 
Guide to Teaching English to Speakers of Other Languages.Cambridge: Cambridge University Press, 66-72.

United Nations Development Programme, (2004) Making Progress on Environmental Sustainability: Lesson and Recommendations from a review of over 150 MDG country experience.

UNDP (United Nations Development Programme). (1990) Human Development Report 1990. New York: Oxford University Press for the UNDP.

Webster, A. (1984) Introduction to the Sociology of Development. London: Macmillan Press.

World Commission on Environment and Development (1987) Our Common Future (the Brundtland Commission). Oxford: Oxford University Press. 